\title{
Approaches to disease management in organic crop production systems: a case of cassava mosaic disease and black pod disease of cocoa
}

\author{
Aregbesola, O.Z $\mathrm{Z}^{1,2^{*}}$ and Owombo, P.T ${ }^{1}$ \\ ${ }^{I}$ Department of Agricultural Science, College of Agriculture Food Science and Technology, Wesley University \\ of Science and Technology, Ondo, Nigeria \\ ${ }^{2}$ Dipartimento di Gestione dei Sistemi Agroalimentari e Ambientali, Università degli Studi di \\ Catania, Italy
}

\begin{abstract}
Organic agriculture in Africa has grown in the past years, to a point where it has become visible and measurable. However, West Africa lags behind other African regions in organic agriculture. Effective management of plant diseases is very important for profitable organic crop production. Economic losses incurred from the devastation of cocoa by the black pod disease of cocoa from different producing regions worldwide are quite enormous and crop losses estimated at $44 \%$ have been reported. Similarly, cassava mosaic disease epidemics are frequent in subsistence agriculture with crop losses throughout sub-Saharan Africa between 19 and 27 metric tonnes and an estimated economic loss of over US\$1.5 billion per year. We review available options for management of black pod disease of cocoa, on an economic security crop, and cassava mosaic disease affecting cassava, a food security crop under organic production system. Additionally, we further encourage organic production of cocoa and cassava in West Africa, and recommend an integrated pest and disease management approach which will involve a systematic combination of the management methods that are feasible for smallholder farmers to practice. Future research needs are also identified.
\end{abstract}

Keywords: Disease management, organic crop production, cassava mosaic disease, black pod disease of cocoa

\section{Introduction}

Organic agriculture is a production system which avoids or largely excludes the use of synthetically compounded fertilizers, pesticides, growth regulators, and livestock additives. To the maximum extent feasible organic farming systems rely on crop rotations, crop residues, animal manures, legumes, green manures, offfarm organic wastes, mechanical cultivation, mineral-bearing rocks, and aspects of biological pest control to maintain soil productivity and tilt, to supply plant nutrients, and to control insects, weeds, and other pests [1-2]. Supporters of organic farming add a social and ethical aspect to the definition of organic agriculture, because they see in it the human dimension, one that is respectful of the environment and in touch with the consumers. Organic agriculture as it is practiced in modern times emerged as part of a growing critique of the negative environmental consequences of modern farming methods [3]. The objectives of environmental, social, and economic sustainability are the basics of organic agriculture [4].

Plant diseases are key constraints to crop production whether under organic or conventional system, and are targets of intervention in many crop production systems in order to get maximum crop output. While still having the fundamental goals of increased crop output and environmental sustainability at heart, there is need to actively mange plant diseases under organic crop production systems. The benefit from organic agriculture are numerous and some of the benefits are: contributing to food security; increasing yields over the long term; combating desertification through improving soil fertility; preventing soil erosion and land degradation, maintaining a healthy environment; increasing incomes with low-cost, locally available and appropriate resources; reducing the financial risk by refraining from using expensive chemical inputs and increasing returns to labour; improving farmers' skills and health [5]. For a detailed review on benefits and problems of organic agriculture see [6].

\subsection{Organic agriculture in Africa}

Organic agriculture in Africa has grown in the past years, to a point where it becomes visible and measurable [7]. Farmers in Africa produce a diversity of organic crops including coffee, cocoa, tea, fruits, medicinal and aromatic plants, olives, cotton, sesame, cereals, oils, nuts, spices and vegetables [8]. Organic farming is significantly more developed in North, South and Eastern Africa than other regions of Africa [9]. The countries with the largest organic agricultural land are Uganda (296, 203 hectares), Tunisia (154, 793 hectares), Ethiopia (140'308 hectares) and Tanzania (62, 486 hectares). Most of this land is used for permanent crops [5]. 
West Africa lags behind other region in organic agriculture, while the region has often been taught of as having a potential for developing a formal certified sector, especially with regard to tropical fruit, few organic trading links have been established. Coffee in Cameroon, palm oil and fruits in Ghana, and cotton in Mali, Senegal and Benin, however, show mentionable certified organic sectors. At the same time, agroecological initiatives promoting rural development and food security, and enhancing soil fertility are relatively strong in West Africa [7].

\subsection{Importance of cocoa and cassava as economic and food security crops}

Cocoa (Theobroma cacao L.) is a perennial plant whose primary diversity centre lies in the Amazon basin [10]. Cocoa is a diploid tree grown in tropical countries [11-12]. Cocoa is grown in a range of conditions such as full sun, or more traditionally under shade. Cocoa production is of global economic importance for the role it plays in the economy of many countries. These include provision of revenue for the government: cocoa contributes to the aggregate export earnings of many cocoa growing countries. Similarly, cocoa also provides a source of income for farmers who are engaged in cocoa production. Processing and marketing of cocoa also provides employment for inhabitants of countries where cocoa is grown. Additionally, cocoa has a lot of health benefits; it's a concentrated food with high nutritive value. It provides carbohydrates, protein, fats and minerals. It is used for making beverages, wine, chocolate, cream and livestock feed [13]. Demand for cocoa has increased tremendously not only as a raw material for chocolate industry, but also for its flavour and other properties which impact several health benefits [12].

Cassava (Manihot esculenta Crantz), is one of the most widely grown staple crops in sub-Saharan Africa (SSA). It has become the continent's most important food security crop, and the stability of its production is vital to the well being of more than 500 million people in SSA [14-16]. Among the cassava-growing regions of the world, Africa accounts for more than $50 \%$ of the global cassava production of 233.8 million metric tons [17].

The potential of the crop is large because it offers a cheap source of food calories and the highest yield per unit area. It also has multiple roles as famine reserve, food and cash crop, industrial raw material and livestock feed. The importance of cassava to the livelihoods of many millions of poor people has made the commodity a target for interventions. New Partnership for African Development has adopted the slogan of "cassava: A powerful poverty fighter in Africa" for its Pan African Cassava Initiative [18-19].

This work aims to review available options for management of crop diseases under organic crop production system with key emphasis on cocoa as an economic security crop and cassava as a food security crop, in addition to encouraging organic production of cocoa and cassava in West Africa.

\section{Diseases of cocoa and cassava}

Below we discuss the major diseases of cocoa and cassava with specific attention to black pod disease of cocoa and cassava mosaic disease.

\section{II.1.Black pod disease of cocoa}

Diseases are major problem responsible for decline in cocoa production and usually causing annual loss of 20-30\%. The major diseases of cocoa include Phytophthora pod rot popularly known as black pod disease (Phytophthora spp.), witches broom (Crinipellis perniiciosa), frosty pod rot (Moniliophthora roreri) and Cocoa swollen shoot disease (Cocoa swollen shoot virus) [12]. The Phytophthora pod rot popularly known as 'black pod disease' on cocoa remains the most important disease having debilitating effects on health of cocoa trees and subsequently on their productive potential worldwide [20].

Phytophthora pod rot is caused by oomycetes of the genus Phytophthora. In Africa the species Phytophthora palmivora and Phytophthora megakarya exist, with P. megakarya been the most damaging species for the cocoa industry. Although P. megakarya only exists in Africa, the species P. palmivora and $P$. capsici are responsible for the disease in South America [21]. Data of economic losses incurred from the devastation of cocoa by the species of these pathogens from different producing regions worldwide is quite enormous. Crop losses estimated at $44 \%$ have been reported [22].

The most striking symptom caused by Phytophthora spp. is pod rot or black pod. Pod lesions begin as small, translucent, hard, dark spots on any part of the pod, at any stage of pod development. Symptoms normally appear about two days after infection under conditions of high humidity. This spot soon turns to a chocolate brown colour and then darken and expand rapidly with a slightly irregular margin so that the whole pod becomes darkened within 14 days. This margin can advance at an average of $12 \mathrm{~mm}$ in 24 hours. Colonised pods shrivel to form a mummified pod which in case of $P$. palmivora provides a reservoir of inoculums for at least 3 years [11,23]. With infections of $P$. megakarya a light bloom of whitish sporangia is often produced about $10 \mathrm{~mm}$ behind the advancing margin of the lesion. This is observed about three days after the appearance of an established lesion or about five days after the initial infection. P. palmivora does not usually produce this 
Approaches to disease management in organic crop production systems: a case of Cassava ....

bloom of sporangia [11]. Pod rot due to P. megakarya are very similar but symptoms appear quicker and sporulation is usually more abundant. P. palmivora and P. megakarya also infect bark, flower cushions and chupons resulting in cankers [11].

\section{II.2.Cassava mosaic disease}

Viruses and their vectors are one of the greatest constraints to cassava production. Two groups of viruses of cassava are of importance in Africa, namely: cassava brown streak viruses (CBSVs) (Potyviridae: Ipomovirus) and the group of cassava mosaic geminiviruses (CMGs) (Geminiviridae: Begomovirus) [16]. Cassava mosaic disease (CMD) is the most limiting biotic factor to cassava production in SSA [24-25]. The CMD pandemics in Africa have developed to become one of the most economically important crop diseases [26]. CMD epidemics are frequent in subsistence agriculture with crop losses throughout SSA between 19 and 27 metric tonnes [16] and an estimated economic loss of over US\$1.5 billion per year [24, 17]. Nine cassava mosaic begomovirus (CMB) species have so far been reported to infect cassava worldwide [27]. In SSA alone, seven of the cassava-infecting CMBs were reported [27, 25].

Cassava plants infected with CMGs express a range of symptoms which depend on the virus species/strain, environmental conditions, and the sensitivity of the cassava host. The most typical symptoms consist of a yellow or pale green chlorotic mosaic of leaves, commonly accompanied by distortion and crumpling [16]. Plants with severe infection have chlorosis which is often associated with premature leaf abscission, a characteristic S-shaped curvature of the petioles of the remaining leaves and an obvious decrease in vegetative growth and tuberous yield [28].

\section{III.1. Management of the diseases of cocoa \\ III. Management of plant diseases in organic agriculture system \\ III.1.1. Resistance}

Breeding for resistance and use of resistant planting materials offers the best long-term management strategy; however, progress in incorporating durable resistance into cultivars with desirable agronomic and quality attributes has been slow. As a genetically variable perennial tree, cocoa improvement presents significant challenges to breeders. Additionally, most breeding programs have focused on yield and quality under intense management regimes and correspondingly low rates of disease, thus neglecting the impact of disease on yields under smallholder farm conditions [23]. Apart from selections in populations of Amazon cocoa for genotypes, which show resistance to Phytophthora pod rot, similar selections in non-Amazon accessions have been made over the years. Some of the cocoa genotypes have been selected for high yield and black pod resistance [29]. A promising approach is to breed for disease escape, which infers that the tree produces the bulk of its crop when climatic conditions are less favourable to the spread of the disease. Breeders could select for short cropping cycle or for profuse flowering early or late in the season, depending on the climate of the area in question [11].

\section{III.1.2. Biological control.}

There has been extensive research into the discovery and application of conventional inundative biological control agents against Phytophthora diseases of cocoa. Although there are many reports of antagonistic and mycoparasitic fungi inhibiting the growth of Phytophthora in vitro, no commercial products have been released or widely adopted by cocoa farmers [23]. Tondje et al. [30] reported successes in the use of Geniculosporium species in the control of P. megakarya. According to Debredt et al. [31], microbial control of black pod disease with PR11 strain of Trichoderma asperellum was promising but not as effective as the chemical methods under the current high disease pressure, and therefore needs to be integrated with other control methods to establish a sustainable management system for black pod disease in Cameroon. Similarly, Hanada et al. [32] suggested that ALF 247 strain of T. martiale could be used for control of black pod disease of cacao, although further studies are required to render this isolate technically and economically efficient as a biocontrol agent on agronomic scale. There is therefore need for more research that will lead to the commercialization of these potential bicontrol agents, which can be made available to farmers after extensive field testing.

\section{III.1.3. Cultural control.}

Management of black pod disease of cocoa in organic production systems relies greatly on the effective and timely application of cultural practices that causes an incomplete synchronization between the virulent pathogen, a susceptible host and a favourable environment. These management strategies have focused on eliminating sources of primary inoculum, and in preventing the movement of inoculums from the soil to the canopy. Optimization of shade and aeration through appropriate spacing and pruning to reduce surface wetness is recommended. Similarly, sanitation including removal of ant tents and appropriate disposal of mummified 
Approaches to disease management in organic crop production systems: a case of Cassava ....

pods, infected pods and pod husk can reduce disease [29]. Bushy farms tend to be more humid and thus favour easy germination of spores, which may cause new infections. Regular weeding and general maintenance is, therefore, essential for reducing black pod disease as it favours quicker drying of the surfaces of the pods [33].

\section{III.1.4. Plant extracts}

A number of researchers reported successes with the use of plant extracts for the control of black pod disease of cocoa. Suprata et al.[34] reported that a formulation (F7) containing flower extract of Eugenia aromatica and leaf extract of Piper betle in the final concentration of $0.5 \%(\mathrm{w} / \mathrm{v})$ significantly suppressed black pod disease of cocoa, and that percentage of infected pods with F7 treatment did not significantly differ from treatment with synthetic fungicide (Dithane M-45), suggesting that the use of the formulation was comparable to Dithane M-45 and can be considered as one of the alternative control for cocoa black pod disease under field conditions. Efficacy of crude extract cocoa infected pods was demonstrated by Fagbohun and Lawal [35], in their study, crude extract from infected cocoa pods compared favourably with conventional fungicides in prevention of black pod disease of cocoa in the field. Awuah [36] also reported the in vitro efficacy of crude extracts of Ocimum gratissimun for the inhibition of Phytophthora palmivora on cocoa pods.

\section{III.1.5. Integrated pest and disease management}

An Integrated pest and disease management (IPDM) program for the control of cocoa diseases must emphasise the integration of all available control methods into a single program. Control measures should include biological control microorganisms, genetic and induced resistance, cultural practices, natural products, and use of chemicals approved for organic cocoa production [37]. The application of IPDM to the cocoa crop enables farmers to choose management strategies suited to their situations and needs. The use of an integrated management system reduces the levels of pests and diseases in the cocoa crop, reduces the inappropriate use of chemicals, provides alternatives for pest and disease management and improves the yield and quality of the cocoa, thereby increasing farmer income [38].

Shade and canopy management practices that increase light and airflow within the canopy, such as appropriate spacing, pruning, and weed control, are also likely to increase flowering and pod development. Frequent and complete harvesting, sanitation, and appropriate disposal of pod mummies, infected pods, and pod husks will reduce the levels of inoculum and flying beetle vectors [39, 23]. Other phytosanitary measures including leaving leaf litter on the farm, removal of ant tents, application of manure to improve plant nutrition will provide further promote the efficacy of the applied control measures. The use of resistant planting materials and natural product biopesticides can also be added to the IPDM programme. Attention has been drawn to biological control using various microorganisms, this is highly promising and amenable to plant disease management under organic production conditions.

\section{III.2. Management of cassava mosaic disease}

There have been a number of approaches suggested for the management of cassava mosaic disease. These approaches centers mainly on phytosanitation and the use of resistant planting materials. Significant eff ort, however, have been made to supplement these two basic approaches with alternatives, including: vector management, cross-protection and cultural practices [40]. As for other plant virus diseases, the strategy for management of CMD focuses on preventing infection, delaying the time of infection, minimizing the effects of the infection once it has occurred, or a combination of the three [26]. There are a growing number of scientific literatures on the control of CMD with each pointing out the limitations in the approaches suggested.

\section{III.2.1. Resistance}

Use of resistant cassava varieties is one of the major approaches that lend itself to the control of cassava virus diseases particularly in the light of the inefficacy and limited feasibility of chemical control approaches. The use of resistant varieties has remained the most economical and ecologically sustainable control measure [41]. During earlier work on breeding for CMD resistance, local and introduced varieties of cassava ( $M$. esculenta) and the progeny of intraspecific crosses between cassava varieties were found to be insufficiently resistant to CMD. Attention then turned to hybrids between cassava and other species, including M. melanobasis and Ceara rubber (M. glaziovii), which were shown to be the most suitable parents [42, 28].

Successes were recorded with efforts at breeding for CMD-resistance which began in the 1930's in Tanzania [42] and Madagascar [43] and seeds of the most resistant lines served as the basis for breeding for CMD-resistance at the International Institute of Tropical Agriculture, Ibadan, Nigeria. Great successes were also recorded in Nigeria through breeding programs at IITA- Nigeria where Nigerian landraces in crosses either directly with 58308 originating from East Africa, or with resistant progenies derived from this clone led to the development of near immune clones in the 1990s [24]. Some of the most important clones from the Tropical Manihot Species series that resulted from this work included: TMS4(2)1425, TMS30337, TMS91934, 
TMS30001, TMS60142 and TMS30572, all of which have been widely distributed across the continent and are now grown by producers in many of Africa's main cassava-producing countries [40].

Ariyo et al. [44] reported that field trials of locally available plants of cassava genotypes Tropical Manihot Esculentum (TME) 4, TME 3, 96/1089A and 96/0160 proved highly resistant to a wide range of cassava mosaic begomoviruses. Similarly, Ogbe et al. [45] reported that two genotypes TME1 and TME 8 were to resistant to CMD under Nigerian conditions. TME 4 is a local land race, with identified dominant ' $R$ 'genes (CMD-2) and has been used as parent in marker assisted selection [46, 41]. The identification of four additional sources of resistance to CMD by the IITA breeding team opened up possibilities for pyramiding these genes thereby assuring durability [40].

With the identification of CMD2 gene that confers resistance to CMD in the 1990s, breeding programs in IITA-Uganda has further advanced lines derived from crosses of cassava carrying the original multigenic resistance with the CMD2 gene. This led to significant success in identification, deployment, and multiplication of farmer-acceptable CMD-resistant varieties in Burundi, Kenya, Rwanda, and Tanzania. These materials are having a significant impact on CMD management in areas affected by the pandemic, but also offer great potential for more general dissemination across SSA as an effective CMD control measure since they combine high levels of resistance to CMD, cassava mealy bug, and cassava green mite, together with many of the farmerpreferred qualities of local landraces [26].

\section{III.2.2. Virus-free planting material}

For many vegetatively propagated plants like cassava, the main source of virus is chronic infection in the plant itself. One of the most successful forms of control has involved the development of virus-free clonesthat is, clones free of the particular virus under consideration [47]. Recent development has made it possible to rapidly produce tens of thousands of virus-free planting materials within a relatively short period of time through the application of the apical meristem and tip culture technology. There is a constant application of this technology at the tissue culture laboratory of the Genetic Resources Centre of the International Institute of Tropical Agriculture, Ibadan, Nigeria. Providing virus-free cassava plantlets for international germplasm exchanges, particularly with respect to importation of newly developed CMD-resistant clones. This has facilitated introduction of CMD-resistant cassava planting materials to tackle the ravaging CMD pandemic in east Africa where the disease is causing serious losses to farmers.

The limitation of this approach to management of CMD has been presented by leading authors on CMD research [16, 40, 28]. The argument been that, material considered virus-free over a period of use could be infected, creating a need purchase new virus-free planting materials by farmers, at a frequency that may be prohibitively high. Nevertheless, the benefits from the use of virus-free cassava in preventing infection of the plant at an earlier stage where infection could cause more devastating economic losses; and also reducing the availability of inoculum for a polycylic spread of the disease through its whitefly vector are benefits a farmer should consider more important than the cost of a more frequent purchase. Additionally, support from government in form of legislation and providing virus-free and / CMD-resistant planting materials to farmers could motivate the farmers and will also help curb the pandemics. This can be made possible by large scale multiplication of material produced from quarantine facilities at regional agricultural research centers within the country.

\section{III.2.3. Phytosanitation}

The use adoption of crop hygiene involving removal of all diseased cassava or other host plants from within and immediately around sites to be used for new plantings has been proposed for the control of CMD [28]. The benefit of this technique is based on reducing or probably eliminating foci of infection on the field. Since farmers in most cases harvest piece meal, sometimes leaving older infected plant to grow with new ones, thus creating conditions that favour the survival and availability of inoculums to initiate new disease cycles. For this approach to be effective, farmers within a farming community need to cooperate to remove CMD infected plants and alternate hosts that could serve foci of infection.

The use of rouging and selection of CMD-free planting materials though known to be useful in small scale research facility concerned with breeding and multiplying cassava for onward distribution to farmer, it is not a common practice among farmer. Farmers are generally reluctant to practice rouging because of perceived reduction in yield due to extra loss that would be incurred as a result of the rouging. In case of a severe outbreak of CMD, all plants on the field may go for it, leaving the farmer with little or nothing to harvest. The limitation to the use of rouging has also been argued particularly in locations where the infections are not severe. In this case, losses due to rouging that actually could be more than what CMD itself will cause if left uncontrolled. Similarly, there are limitations to selection of CMD-free planting materials from relatively healthy ones in cases of latent infection of relatively resistant materials, and also in cases of severe infection when the farmer can't 
find any plant to select from. However, these approaches are still useful after a consideration of the prevailing situations and also when used in combination with other CMD management methods.

\section{III.2.4. Vector management}

Otim et al. [48] suggested an urgent need to develop a balanced approach to CMD/CBSD/vector management, which can combine the deployment of CMD/CBSD/whitefly-resistant cultivars and alternative control methods, such as the use of B. tabaci natural enemies. Although effective sources of resistance have been identified for non-Bemisia whitefly species in Latin America [49], preliminary results suggest that these are less effective against African $B$. tabaci, and further research into alternative sources of resistance to $B$. tabaci is required [50-51].

However, successes have been recorded with the identification of effective parasitoids of $B$. tabaci across Africa. Reports indicate the availability of parasitoids of $B$. tabaci and their potentials in managing the organism in SSA. From these reports, Encarsia spp. and Eretmocerus spp. have been widely observed [52-57]. Utilising theses species for management of $B$. tabaci of cassava in Africa is promising.

\section{III.2.5. Cross-protection}

The application of cross protection, which involves protecting a susceptible plant from infection by a more virulent one, has been used with great successes in the management of Citrus tristeza virus. It is worthy of note to say there are a number of reports suggesting the successes in protection of cassava plant from a more virulent strain through previous infection by a mild strain [58, 40,28]. To determine if indeed mild strains of East African cassava mosaic virus (EACMV-UG) were providing a form cross protection, Owor et al. [59], carried out an experiment in Central Uganda. Plant grown from initially CMD-free parent and initially infected with mild strain of EACMV-UG were grown and subsequent pattern of infection, symptoms expression and tuberous root production were assessed. Plants grown from initially CMD-free parent developed more severe disease and yielded less than plants derived from mildly diseased parent [24]. An important consideration in the implementation of such an approach will be to determine where mild strain protection works and where it does not work, in view of the diversity of virus occurrence [26]. Additionally, one will also need to consider the willingness of the farmers to adopt such method. There is also the risk of the viruses synergising to produce a more severe disease. All this makes this approach still theoretical at the moment as it has not been used on a large scale anywhere to mange CMD.

\section{III.2.6. Crop spacing}

The benefits of close spacing in decreasing the proportion of infected plants within a stand has be demonstrated in experiments on cassava [60,61, 28]. The effect of plant density in the management of CMD can be observed in [62], when used in combination with other control measures, planting cassava at a higher density can help reduce the progress of CMD. It is however necessary to point out that planting cassava at high density favours the spread of cassava bacterial blight (CBB). The application of this method may be limited to locations where $\mathrm{CBB}$ is not a major challenge.

\section{III.2.7. Planting date}

Even if an area-wide crop-free period is not adopted, some amount of vector and virus inoculum can often be avoided by planting early or late [63]. This can be attained by adopting planting date that avoid exposing young vulnerable plants to infection at times when there are likely going to be the highest population of viruliferous whiteflies [64-65].

In coastal districts of Kenya, the main spread of CMD by vectors occurs during the early rains from mid-May to mid-July and there are likely to be advantages in planting later in the year provided conditions are not so dry that crop establishment and subsequent growth are impaired [66, 28]. There is a somewhat similar situation in the forest areas of Ivory Coast, where virus spread occurs throughout the year, but is most rapid from March to July and least rapid from August to November during the latter part of the rainy season [67, 28]. Hiljea et al., [63] presented a number of success stories with this approach on other crop pathosystem: okra in Mexico [68], tomato in Egypt [69], cotton in northern Mexico [70-71], bean in Egypt [72] and tobacco in India [73].

\section{III.2.8. Varietal mixtures}

Orisu et al. [74] demonstrated that varietal mixture has the capacity to reduce the progress of CMD. In their experiment, it was observed that consistently low incidence and lower populations of adult whiteflies were recorded in Ebwanatereka (a CMD susceptible variety) grown in mixtures with resistant varieties than when it was gown alone. The effect was attributed to differences in the food resource concentration, improved efficacy of natural enemies and moderated micro-climatic conditions associated with varietal mixtures. The results 
suggested that resistant varieties provide protection to susceptible varieties through a reduction of intra-plot spread.

The experiences from farmers' field on the effect of varietal mixtures in reducing the progress of CMD was observed during the 1990s epidemic of CMD in Uganda, where losses were much less in districts where many varieties were being grown than where there was almost complete reliance on the susceptible variety Ebwanateraka [75, 28]. One of the implications of these is that since in most cases farmers and farming communities grow a mixture of variety, having resistant varieties as part of their planting materials will help reduced the effect of CMD with no extra effort. However, there are high probabilities that the resistant variety may lose its ability to protect the susceptible variety after a long period of cultivation, higher inoculum pressure and increased whitefly abundance.

\section{III.2.9. Intercropping and strip cropping}

Intercropping refers to spatial arrays of crops including two or more plant species in close proximity to each, within a given plot [63]. Results from the preliminary studies by Fargette and Fauquet [76] suggested that the density rather than the height of the maize barrier used as the intercrop affected the distribution and incidence of the disease and indicating that the differences of disease incidence was mainly due to changes in the sizes of whitefly populations. In subsequent studies better results were obtained. Ahohuendo and Sarkar, [77] reported a partial control of CMD in Benin by intercropping cassava with maize, cowpea and groundnut. Similar results were obtained in Cameroon where Fondong et al. [78] and Fondong et al. [79] intercropped cassava with cowpea and maize. Additionally, control of CMD through the management of its whitefly vector can also be achieved through a similarly cropping system like strip cropping. Ewusie et al. [80] reported that a significantly lower numbers of immature (egg and nymph) and adult B. tabaci were found in cassava plots surrounded on all sides by five rows of both cotton and Jatropha curcas, clearly demonstrating the potential of strip cropping as a management option for the suppression of B. tabaci populations.

\section{III.2.10. Training and extension education}

In SSA where many farmers are illiterate, and having smallholder farms, educating them on the basics of the epidemiology and control of CMD will help to large extent in the management of the disease. Increasing the knowledge of all stakeholders affected by the CMD pandemic has been an important component of CMD management programme [26]. Researchers are constantly receiving further information and training through their participation in workshops and other scientific activities, similarly, farmers who feel the immediate effect of CMD should be trained and orientated, on the epidemiology and control of CMD as this awareness and orientation will promote the adoption of recommended CMD management practices. The farmer needs to understand why the recommended control measures are better than the ones he is used to for him to make a decision to adopt them. Legg et al. [26] reported progress with regards to farmers and researchers from East and Central Africa where the print media, radio and farmers field schools are used to disseminate the right management practices to farmers. More coordinated training programmes should also be organised for agricultural extension agents in order to make the training of the farmers more effective.

\section{III.2.11. Integrated pest and disease management}

The challenge of developing a comprehensive integrated pest and disease management (IPDM) approach for CMD remains unmet, since host plant resistance has been so successful, particularly in the management of the CMD pandemic in East Africa [15]. However, adding the vector roles of B. tabaci to the spread of CMD, to its effects as pest causing serious damage and limiting production of cassava, it becomes necessary to combine a number of management strategies in a systematic and coordinated integrated pest and disease management plan. A number of possible control measures previously described can be combined. Good agronomic practices, use of $\mathrm{CMD} / B$. tabaci resistant cassava planting materials, biological control if well combined will offer a more comprehensive pest and disease management approach. With extension education and training farmers can be introduced to these integrated approach of managing the CMD pandemics and the pest/vector problem posed by $B$. tabaci

\section{Conclusion}

The merits of organic agriculture far outweigh its constraints, some of the merits have been previously stated in this paper, others are its contribution to sustainable agriculture and sustainable development through the ecosystem and consumer friendly approaches of production. Effective plant pest and disease management is paramount for profitability of organic production. Several ecosystem and consumer friendly approaches including the use of resistant planting materials, biological control and cultural control have been suggested. To further improve the efficacy of disease and pest management, a systematic combination of management approaches in to an integrated pest and disease management program for cocoa and cassava must be 
emphasised. Since this give farmers the opportunity to choose methods that are feasible and practicable by them. More research attention has to be given to the commercialisation of identified biological control agents that could used for disease and pest management in both the cassava and cocoa pest-pathosystems. There is need for more research on combining disease resistance with vector resistance. Furthermore the merits of some of the approaches that still appear unacceptable to farmers, for instance cross-protection i.e. the use of mild strain of a virus to protect the crop against a more virulent strain need further research before recommending such approach to farmers. Similarly, the efficacy of some other cultural methods viz-a-viz- the effects of their use on other plant diseases affecting the crop needs more research attention. For instance, close spacing in cassava helps manage CMD while it is more likely to promote an outbreak of cassava bacterial blight on CBB susceptible varieties. Attention should also be given to extension education/ training of farmers.

\section{References}

[1]. United States Department of Agriculture (USDA), Report and Recommendations on Organic Farming. United States Department of Agriculture, July 1980.

[2]. R. Troedson, Organic farming - A Growing Role in Canadian Agriculture? Background information brief no 20. Queensland parliamentary library, publications and resources Section (Brisbane, Australia, 1991) 1-34.

[3]. M. Barbercheck, N.E. Kiernan, A.G. Hulting, S. Duiker, J. Hyde, H. Karsten, and E. Sanchez, Meeting the 'multi-' requirements in organic agriculture research: Successes, changes and recommendation for multifunctional, multidisciplinary, participatory projects, Renewable Agriculture and Food Systems 27(2), 2011, 93-106.

[4]. S.K. Yadav, S. Babu, M.K. Yadav, K. Singh, G.S. Yadav., and S. Pal, A review of organic farming for sustainable agriculture in Northern India, International Journal of Agronomy 2013, 2013, 1-8.

[5]. H. Bouagnimbeck, Organic farming in Africa, in Willer, Helga and Lucas Kilcher (eds), The World of Organic agriculture statistics and emerging and trends 2009 (FIBL-IFOAM Report. IFOAM, Bonn; FiB1, Frick, ITC, Geneva, 2009) 114-126.

[6]. W.B Bello, Problems and Prospect of Organic Farming in Developing Countries, Ethiopian Journal of Environmental Studies and Management 1(1), 2008, $36-43$.

[7]. N. Parrott, B. Van Elzakker, and A. Eco, Organic and like-minded movements in Africa. International Federation of Organic Agriculture Movements IFOAM (Tholey-Theley,Germany: IFOAM, 2003).

[8]. Yussefi, M., and Willer, H, Organic farming worldwide 2007: overview and main statistics. The World of Organic AgricultureStatistics and Emerging Trends 2007 (FIBL-IFOAM Report. IFOAM, Bonn; FiB1, Frick, ITC, Geneva, 2007) 9-16.

[9]. P. Jules, R. Hine, and S. Twarog. Organic agriculture and food security in Africa, UNEP-UNCTAD Capacity-Building Task Force on Trade (New York and Geneva: United Nations Conference on Trade and Development/United Nations Environment Programme, 2008).

[10]. E.S. dos Santos, C.M. Cerqueira-Silva1, D. Clement, and Luz, E.D, (Resistance gradient of black pod disease in cocoa and selection by leaf disk assay, Crop Breeding and Applied Biotechnology 11, 2011, 297-303.

[11]. Wood, G.A.R. and Lass, R.A. "Cacao", 4th edn. (Oxford, UK: Blackwell, 2001) 620.

[12]. S.A. Naganeeswaran, E.A. Subbian, and M. Ramaswamy, Analysis of expressed sequence tags (ESTs) from cocoa (Theobroma cacao L.) upon infection with Phytophthora megakarya, Bioinformation 8(2), 2012, 065-069.

[13]. T.T. Amos, An analysis of productivity and Technical Efficiency of Small-holder cocoa farmers in Nigeria, J. Soc. Sci. 15 (2), 2008, 127-133.

[14]. A.L. Charvez, J.M. Bedoya, T. Sánchez, C. Iglesias, C, H, Ceballos, and W, Roca, Iron, carotene, and ascorbic acid in cassava roots and leaves, in, Food and Nutrition Bulletin 21 (4) (Japan: The United Nations University Press Tokyo, 2000) $410-413$.

[15]. J.P. Legg, Emergence, spread and strategies for controlling the pandemic of assava mosaic virus disea se in east and central Africa, Crop Protection 18, 1999, 627-637.

[16]. J.P. Legg, and J.M. Thresh, Cassava virus diseases in Africa., Proc. Conference, Plant Virology in Sub-Saharan Africa, IITA, Ibadan, Nigeria, 2004, 517-552.

[17]. O.J. Alabi, P. Lava Kumar, and R.A. Naidu, Multiplex PCR for the detection of African cassava mosaic virus and East African cassava mosaic Cameroon virus in cassava, Journal of Virological Methods 154, 2008, 111-120.

[18]. E. Whingwiri, NEPAD Pan Africa Cassava Initiative, ISTRC-AB Symposium, Mombasa, Kenya, 2004.

[19]. L. Sanni, B. Maziya-Dixon, M. Patino, M. Akoroda, C. Ezedinma, R. Okechukwu, and J. Lemchi, Value addition to cassava in Africa: Challenges and opportunities, African Crop Science Conference Proceedings 7, 2005, 583-590.

[20]. A.H. Otuonye, A.Y. Adeoti, S.O. Agbeniyi, P.O. Aikpokpodion, O. Enikomehin, and T.O. Popoola, Evaluation of the susceptibility of local cocoa germplasms in Nigeria to Phytophthora pod rot disease using the leaf discs technique, Journal of Food, Agriculture \& Environment 5 (3\&4), 2006, 327-329..

[21]. D. Pauline, M. Ducamp, and P. Lachenaud, New sources of resistance to Phytophthora megakarya identified in wild cocoa tree populations of French Guiana, Crop Protection 27, 2008, 1143-1147.

[22]. United Nations Environment Programme (UNEP), Integrated Assessment of Trade Liberalization and Trade-Related Polices: A Country Study on the Exports Crop Sector in Nigeria (New York and Geneva, 2002) 47-57.

[23]. D. Guest, Black pod: Diverse pathogens with a global impact on cocoa yield, Phytopathology 97, 2007, 1650-1653.

[24]. J.M. Thresh, D. Fargette, G.W. Otim-Nape, Effects of African cassava mosaic virus on the yield of cassava, Tropical Science, 28, 1994, 34-37.

[25]. R.C. Aloyce, F. Tairo, P. Sseruwagi, M.E.C. Rey, and J. Ndunguru, A single-tube duplex and multiplex PCR for simultaneous detection of four cassava mosaic begomovirus species in cassava plants, Journal of Virological Methods 189, $2013,148-156$.

[26]. J.P. Legg, B. Owor, B. Sseruwagi, and J. Ndunguru, Cassava mosaic virus disease in East and Central Africa: epidemiology and management of a regional pandemic, Advances in Virus Research 67, 2006, 365-417

[27]. C.M. Fauquet, R.W. Briddon, J.K. Brown, E. Moriones, J. Stanley, M. Zerbini, and X. Zhou, Geminivirus strain demarcation and nomenclature, Archive of Virology 153, 2008, 783-821.

[28]. J.M. Thresh, and R.J. Cooter, Strategies for controlling cassava mosaic virus disease in Africa, Plant Pathology 54, 2005, 587-61.

[29]. S.O. Agbeniyi, K. Badaru and P.O. Aikpokpodion, Integrated protection strategies for the Management of Black pod disease in Nigeria, Proc.14th International Cocoa Research Conference, Accra, Ghana, 2003, 1373-1376. 
[30]. P.R. Tondje, K.P. Hebbar, G. Samuels, Bowers, G.H., Weise, S., Nyemb, E . Begoude, D., Foko, J and D. Fontem, Bioassay of Geniculosporium species for Phytophthora megakarya biological control on cacao pod husk pieces, African Journal of Biotechnology 5 (8), 2006, 648-652.

[31]. P, Deberdt, C.V. Mfegue, P.R. Tondje, M.C. Bon, M. Ducamp, B.A.D. Begoude, M. Ndoumbe-Nkeng, P.K., Hebbar, and C. Cilas, Biological Control 44, 2008, 149-159.

[32]. R.E. Hanada, A.W. Pomella, W. Soberanis, L.L. Loguercio, and J.O. Pereira, Biocontrol potential of Trichoderma martiale against the black-pod disease (Phytophthora palmivora) of cacao, Biological Control 50, 2009, 143-149.

[33]. K.L. Opeke, Cocoa, in, Tropical commodity tree crops (Ibadan, Nigeria: Spectrum books, 2005) 89-121.

[34]. D. N. Suprapta, M. Sudana, I G.N.A. S. Wirya, and P. Sudiarta, Plant extracts to control cocoa black pod disease caused by Phytophthora palmivora, Journal of the International Society for Southeast Asian Agricultural Sciences, 13(2), 2007, 92-125.

[35]. E.D. Fagbohun, and O.U. Lawal, A field trial of crude extract from Phytophthora palmivora - infected cocoa pods to control black pod disease in a farm in Iworoko Ekiti, Ekiti State, Journal of Agricultural Biotechnology and Sustainable Development, 3(6), 2011, $100-104$.

[36]. R.T. Awuah, invitro use of extracts of Ocimum gratissimum and Cympogon citratus aginst Phytophthora palmivora causing black pod disease of cocoa, Annals of Applied Biology, 124, 1994, 173-178.

[37]. T.O. Adejumo, Crop protection strategies for major diseases of cocoa, coffee and cashew in Nigeria, African Journal of Biotechnology 4 (2), 2004, 143-150.

[38]. J. Konam, Y. Namaliu, R. Daniel, and D.I. Guest, 2008. Integrated pest and disease management for sustainable cocoa production: a training manual for farmers and extension workers. Australian Centre for International Agricultural ResearchMonograph No. 131, $2008,36 \mathrm{pp}$.

[39]. I.P. Aryantha, R. Cross, and D.I. Guest, Suppression of Phytophthora cinnamomi in potting mixes amended with uncomposted and composted animal manures, Phytopathology 90, 2000, 775-782.

[40]. J.P. Legg, and C.M. Fouquet, Cassava mosaic geminiviruses in Africa, Plant Molecular Biology 00, 2004, 1-14.

[41]. A.O. Ariyo, G.I. Atiri, A.G.O. Dixon, S. and Winter, The use of biolistic inoculation of cassava mosaic begomoviruses in screening cassava for resistance to cassava diseases, Journal of Virological Methods 137, 2006, 43-50.

[42]. R.F.W. Nichols, 1947. Breeding cassava for virus resistance, East African Agricultural Journal 12, 1947,184 - 94.

[43]. G. Cours, Le Manioc à Madagascar, Mémoires de l'Institut Scientifique de Madagascar, Série B, Biologie Végétale 3, 1951, 203400.

[44]. A.O. Ariyo, M. Koerbler, A.G.O. Dixon, G.I. Atiri, and S. Winter, Development of an efficient virus transmission technique to screen cassava genotypes for resistance to cassava mosaic disease. Proc. Deutscher Tropentag Conference on International Agricultural Research for Development, 2003, Gottingen, Germany.

[45]. F.I. Ogbe, G.I. Atiri, A.G.O. Dixon, G. Thottappilly, Symptom severity of cassava mosaic disease in relation to concentration of African cassava mosaic virus in different cassava genotypes, Plant Pathol. 52, 2003, 84-91.

[46]. A.O. Akano, A.G.O. Dixon, C. Mba, E. Barrera, M. Fregene, Genetic mapping of a dominant gene conferring resistance to cassava mosaic disease, Theor. Appl. Genet. 105, 2002, 521-525.

[47]. R. Hull, Comparative plant virology (US, Elsevier Academic Press, 2009) 376.

[48]. M. Otim, G. Kyalo, S. Kyamanywa, P. Asiimwe, J.P. Legg, M. Guershon, and D. Gerling, Parasitism of Bemisia tabaci (Homoptera: Aleyrodidae) by Eretmocerus mundus (Hymenoptera: Aphelinidae) on cassava, International Journal of Tropical Insect Science 28(3), 2008, 158-167.

[49]. A. C. Bellotti, and B, Arias, Host plant resistance to whiteflies with emphasis on cassava as a case study, Crop Protection 20, 2001, 813-823.

[50]. J.P. Legg, G. Okao-Okuja, R. Mayala, J.B. Muhinyuza, Spread into Rwanda of the severe cassava mosaic virus disease pandemic and associated Ugandan variant of East African cassava mosaic virus (EACMV-Ug), Plant Pathol. 50 (6), 2001, 796-796.

[51]. J.P. Legg, S.C. Jeremiah, H.M. Obiero, M.N. Maruthi, I. Ndyetabula, G. Okao-Okuja, H. Bouwmeestera, Bigirimanag, S., TataHangyh, W., Gashakai, Mkamiloj, G., Alicai, T and Lava Kumar, P Comparing the regional epidemiology of the Cassava mosaic and cassava brown streak virus pandemics in Africa, Virus Research, 159(2), 2011, 161-170.

[52]. A. Cudjoe, J. Gyamenah, and B, James, Ghana: in, Pamela K. Anderson and Francisco J. Morales (eds.), Whitefly and whiteflyborne viruses in the tropics: Building a knowledge base for global action (Columbia: Centro Internacional de Agricultura Tropical, 2005) 24-29.

[53]. B. Gbaguidi, B. James, and S. Saizonou, Benin, in, K. Pamela, Anderson and J. F Morales (eds.), Whitefly and whitefly-borne viruses in the tropics: Building a knowledge base for global action (Columbia: Centro Internacional de Agricultura Tropical, 2005) 30-34.

[54]. N.C. Echendu, J.B. Ojo, B. James, and B. Gbaguidi, Nigeria, in, Pamela K. Anderson and Francisco J. Morales (eds.), Whitefly and whitefly-borne viruses in the tropics: Building a knowledge base for global action (Columbia: Centro Internacional de AgriculturaTropical, 2005) 35-39.

[55]. N. Ntonifor, B. James, B. Gbaguidi, and A. Tumanteh, Cameroon: P. Sseruwagi, J.P. Legg, and G.W. Otim-Nape, Cameroon, in, K. Pamela, Anderson and J. F Morales (eds.), Whitefly and whitefly-borne viruses in the tropics: Building a knowledge base for global action (Columbia: Centro Internacional de Agricultura Tropical, 2005) 40- 45.

[56]. P. Sseruwagi, J.P. Legg, and G.W. Otim-Nape, Uganda, in, K. Pamela, Anderson and J. F Morales (eds.), Whitefly and whiteflyborne viruses in the tropics: Building a knowledge base for global action (Columbia: Centro Internacional de Agricultura Tropical, 2005) 46- 53.

[57]. J. Kamau, P. Sseruwagi, and V. Aritua, (2005) Kenya, in, K. Pamela, Anderson and J. F Morales (eds.), Whitefly and whiteflyborne viruses in the tropics: Building a knowledge base for global action (Columbia: Centro Internacional de Agricultura Tropical, 2005) 54-60.

[58]. B. Owor, Effect of cassava mosaic geminiviruses (CMGs) on growth and yield of a cassava mosaic disease (CMD) susceptible cultivar in Uganda and cross protection studies, M.Sc. thesis, Makerere University, Kampala, Uganda, 2002.

[59]. B. Owor, J.P. Legg, R. Obonyo, G. Okao-Okuja, S. Kyamanywa, and M.W. Ogenga-Latigo, Field studies of cross protection with cassava in Uganda, Journal of Phytopathology 152, 2004, 243-249.

[60]. D. Fargette, C. Fauguet, Grenier, E. and J.M. Thresh, The spread of African cassava mosaic virus into and within cassava fields, Journal of Phytopathology 130, 1990, 289-302.

[61]. J. Egabu, D.S.O. Osiru, E. Adipala, J.M. Thresh, Influence of plant population on cassava mosaic disease in central Uganda. African Crop Science Proceedings 5, 2002, 439-443.

[62]. D. Fargette, C. Fauquet, J.C. Thouvenel, Yield losses induced by African cassava mosaic virus in relation to the mode and the date of infection. Tropical Pest Management 34, 1988, 89-91. 
[63]. L. Hiljea, H.S. Costab, A.S Philip, Cultural practices for managing Bemisia tabaci and associated viral diseases, Crop Protection 20, 2001, 801-812.

[64]. A. Adipala, B.A. Byabakama, M.W. Ogenga-Latigo, and Otim-Nape, G.W. Effects of planting dates and varietal resistance on the development of cassava mosaic disease in Uganda, African Plant Protection 4, (1998), 71-79.

[65]. L.A. Calvert, and J.M. Thresh, Viruses and virus diseases of cassava, in R.J. Hilocks, J.M., Thresh and A.C Belloti (eds.) Cassava: Biology, production and Ultilisation (UK: CAB publishing, 2002) 237-258.

[66]. I.A.D. Robertson, The whitefly Bemisia tabaci (Gennadius) as a vector of African cassava mosaic virus at the Kenya coast and ways in which the yield losses in cassava Manihot esculenta Crantz caused by the virus can be reduced, Insect Science and its Application 8, 1987, 797-801.

[67]. D. Fargette, M.J. Jeger, C. Fauquet, L.D.C. Fishpool, Analysis of temporal disease progress of African cassava mosaic virus, Phytopathology 84, 1994, 91-8.

[68]. A. Diaz-Franco, A.S. Obregón, Influencia de la fecha de siembra y la poda sobre la produccion de cultivares de okra, Agron. Mesoamericana (Costa Rica) 8, 1997, 93-98.

[69]. S.S. El-Gendi, K.M. Adam, M.A. Bachatly, Eff ect of the planting date of tomato on the population density of Bemisia tabaci (Genn.) and Heliothis armigera (HB), viral infection and yield. Arab J. Agric. Sci. 5, 1997, 135-144.

[70]. A. Hernảndez, and J.J. Pacheco, 1998. Changing a planting date: a silverleaf whitefly case, Proc. of the Beltwide Cotton Conference, National Cotton Council, Memphis, TN, 1998, 574-577.

[71]. A. Hernảndez-Jasso, J.J. Pacheco-Covarrubias, Control of the cotton whitefly with planting dates in the Yaqui Valley, Sonora, Mexico, Fitotec. Mexicana 21, 1998, 83-92.

[72]. S.A.G. Metwally, Eff ect of planting date and certain weather factors on the population fluctuations of three insect pests infesting kidney beans in Qualyobia governorate, Egypt. J. Agric. Res. 77, 1999, 139-149.

[73]. V.C. Patel, H.K. Patel, Inter-relationship between whitefly (Bemisia tabaci Genn.) population and the incidence of leaf curl in bidi tobacco (Nicotiana tabacum L.) in relation to diff erent planting dates, Indian J. Entomol. 28, 1966, 339-344.

[74]. D.S.O. Osiru, W.S. Sserubombwe, P. Sseruwagi, J.M. Thresh, and G.W. Otim-Nape, Effects of Cassava mosaic virus disease on the growth and yield of cassava - some highlights from Makerere experiments, African Crop Science Journal 7(4), 1999, $511-522$.

[75]. G.W. Otim-Nape, T. Alicai, J.M. Thresh, Changes in the incidence and severity of cassava mosaic virus disease, varietal diversity and cassava production in Uganda, Annals of Applied Biology 138, 2001, 313-27.

[76]. D. Fargette, and C. Fauquet, A preliminary study on the influence of intercropping maize and cassava on the spread of African cassava mosaic virus by whiteflies, Aspects Appl. Biol. 17, 1998, 195-202.

[77]. B.C. Ahohuendo, and S. Sarkar, Partial control of the spread of African cassava mosaic virus in Benin by intercropping, J. Plant Dis. Prot. 102, 1995, 249-256.

[78]. V.N. Fondong, E. Adipala, J.M. Thresh, Spread of African cassava mosaic geminivirus at four agroecological locations of Cameroon, African Crop Science Conference Proceedings 3, 1997, 1035-49.

[79]. V.N. Fondong, J.M. Thresh, S. Zok, Spatial and temporal spread of cassava mosaic virus disease in cassava grown alone and when intercropped with maize and/or cowpea, Journal of Phytopathology 150, 2002, 365-74.

[80]. E.A. Ewusie, M.N. Parajulee, D. Aba Adabie-Gomez, and D. Weste, Strip Cropping: A Potential IPM Tool for Reducing Whitefly, Bemisia tabaci Gennadius (Homoptera: Aleyrodidae) Infestations in Cassava, Journal of Applied Ecology 17, 2010, $109-119$.

Address:

Aregbesola Oluwatosin Zacheus

Dipartimento di Agricoltura, Alimentazione e Ambiente (Di3A)

Sezione di Entomologia applicata

Università degli Studi

Via Santa Sofia, 100

95123 Catania (Italy) 